\title{
Mesopotamian Marshlands: Salinization Problem
}

\author{
Sama AlMaarofi ${ }^{1}$, Ali Douabul ${ }^{2}$, Hamid Al-Saad ${ }^{2}$ \\ ${ }^{1}$ Biology Department, University of Waterloo, Waterloo, Canada; ${ }^{2}$ Department of Marine Environmental Chemistry, Marine Science \\ Center, University of Basra, Basra, Iraq. \\ Email: adouabul@mscbasra.org, adouabul@hotmail.com
}

Received July $23^{\text {rd }}, 2012$; revised August $24^{\text {th }}, 2012$; accepted September $18^{\text {th }}, 2012$

\begin{abstract}
Salinization becomes a very serious problem affecting the restoration assessment of the newly re-flooded marshes of the Mesopotamian southern Iraq. From mid-1970 to early-1990, the whole marsh area was influenced by water shortage and desiccation processes. Increasing the average salinity level in the re-flooded marshes is acting versus their recovery progress and significantly affecting their aquatic biota. This study will examine the contributions of dams' construction and desiccation on increasing the salinity level with in the Mesopotamian marshlands overtime. Water discharge and salinity concentration were monitored in the direct water inputs and outlets of the three marshlands from May 2006 to February 2007 on a monthly basis, while salinity and major ions concentrations including " $\mathrm{Ca}^{1+}, \mathrm{Mg}^{2+}, \mathrm{Cl}^{1-}$, and $\mathrm{SO}_{4}^{2-}$ " were monitored in 28 re-flooded marshes from March 2005 to August 2008 on a seasonal basis. The study indicate that increasing the salinity level in the Mesopotamian marshlands is due to three reasons: 1) The overtime increasing in the salinity level of their direct water inputs, due to dams' constructions; 2) the increase of the Arab Gulf tide via Shatt Al-Arab river due to the reduction of the water level in the outlets of the Central and Al-Hammar marshlands; and $3)$ the huge accumulation of salts due to desiccation.
\end{abstract}

Keywords: Mesopotamian Marshlands; Water Shortage; Desiccation; Salinization; Major Ion Sources

\section{Introduction}

The Mesopotamian marshlands southern Iraq $\left(29^{\circ} 55^{\prime} \mathrm{N} \&\right.$ $32^{\circ} 45^{\prime} \mathrm{N}$ to $\left.45^{\circ} 25^{\prime} \mathrm{E} \& 48^{\circ} 30^{\prime} \mathrm{E}\right)$, were one of the biggest wetlands in the Middle East and used to occupy an area of $20,000 \mathrm{~km}^{2}$ [1], have been dramatically affected by several anthropogenic activities mainly dams' construction and desiccation. These actions are directly influence the hydrological regime of the area. The Tigris and the Euphrates Rivers "the Two Rivers" are the major water resources of the marshlands comparing to the partial seasonal discharge from the Iranian territories southern east the Mesopotamian, precipitation, and groundwater. Since the creation of the Mesopotamian marshlands their hydrological fluctuation and seasonal cycle have been significantly motivated by the hydrological regime of the Two Rivers [2-4]. Towards the ends of the twentieth century, specifically during mid-1970's, the natural hydrological cycle of the Two Rivers has changed dramatically due to dams' construction in Turkey, where they originate. This led to reduce their annual quantity of water as well as their actual water discharge. Not surprising that the sequences of the water shortage from such projects can reach and affect the hydrological system of Mesopotamian marshlands. On the other hand, the desiccation processes that initiated in early 1990's during
Sadam Husain's regime led to lose $90 \%$ of the total marshlands area by 2000 [5]. Some of the dried marshes were converted into agricultural field, while more than $70 \%$ of the desiccated areas became deserts. The drainage process was started by constructing major hydraulic drains and channels. The main work also includes building several embankments across the marshlands area to cut the circulation of the water across the Central, Al-Hawizeh, and Al-Hammar marshlands and control the draining processes [6-8]. Then the water was left to evaporate leaving a thick salty-sheet on top of the dried areas causing what is known as salinization [5,7]. In April 2003, the dried area of the Mesopotamian were inundated and three years later $30 \%$ of the marshlands were reflooded again with the help of the new government of Iraq and the remaining population of the Arab marshlands. Meanwhile, the new re-flooded marshes become the focal point in order to examine their ability to recover. The great water pulse encourages the remaining of the aquatic habitat to rebirth for the next few years and gave the hope to restore the ecological values of the Mesopotamian marshlands. However, the impact of salinization still exists, which made many scientists to believe that the natural ecological recovery of the re-flooded marshes may not be successful. Thus their recovery rate can become less effective to exhibit the 
same historical functions and the re-flooded marshes' ecosystems may lose their recreational ability [9]. Salinization problem has been a concerning problem in different wetlands in Australia, New Zealand, and Europe. The impacts of increasing salinity in wetlands can significantly 1) affect the biodiversity and assemblage of phytoplankton [10]; 2) change the distribution and abundance of macrophytes and fish [11,12]; 3) alter the proportions of major ion in the water and 4) magnify the effect of toxic component in the water and the sediment [13]. Although the hydrological regime of the re-flooded marshes are showing different levels of recovery responses, the flooding process was chaotic and some of the re-flooded marshes received constant water supply with bad water quality [14]. The water quantity and quality become the focus of many researches in order to assess the recovery potential of the re-flooded marshes and understand their ecological health $[14,15]$. This paper aimed to illustrate the impact of water shortage and desiccation and their contribution to the increasing in the salinity level of the Mesopotamian marshlands overtime.

\section{Study Description and Methodology}

The Mesopotamian marshlands are historically divided in to three major marshlands: The Central Marshland (CM),
Al-Hawizeh marshland (HZ), and the Al-Hammar marshland (HM). From May 2006 to February 2007, water discharge (WD) and salinity concentrations were monitored in the direct water inputs and outlets of the Mesopotamian on a monthly basis. On the other hand, Salt contents and major ions concentrations including: calcium $\left(\mathrm{Ca}^{1+}\right)$, magnesium $\left(\mathrm{Mg}^{2+}\right)$, chloride $\left(\mathrm{Cl}^{1-}\right)$, and sulfate $\left(\mathrm{SO}_{4}^{2-}\right)$ in 28 re-flooded marshes were determined in water samples from March 2005 to August 2008. Figure 1 shows the monitored locations during the study period. Salinity concentrations were measured using a WTW Multi-meter model $350 \mathrm{i}$. Water samples $(1 \mathrm{~L})$ for major ions determination were collected from the water surface (depth $\sim 30 \mathrm{~cm}$ ) using a horizontal Van Dorn sampler and were filtered immediately using pre-weighted Whatman GF/F $0.7 \mu \mathrm{m}$ filters. Major ion concentrations were determined according to the standard procedures described in [16]. The historical water discharge data from 1940 to 2005 that estimated at Al-Nasiriyah and Al-Kut stations "the closest points to the Mesopotamian marshlands", respectively were taken from [6] unpublished reports. The historical salinity concentrations of the Two Rivers were used taken from [2]. The historical salinity and major ions concentrations of the Mesopotamian marshlands were taken from [17]. A principal components analysis (PCA) was used to examine the main dominant

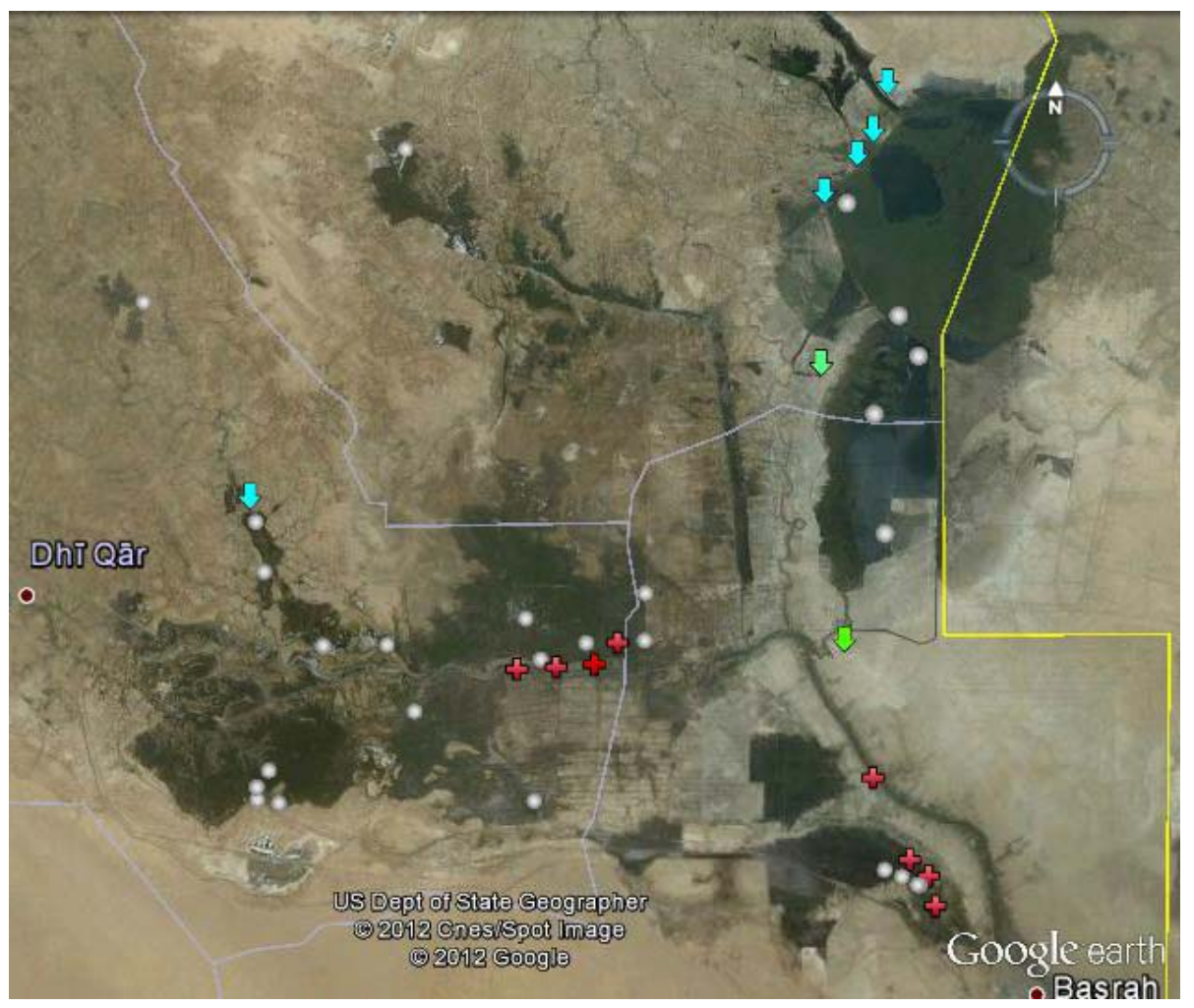

Figure 1. Satellite image of the monitored re-flooded marshes in the Mesopotamian marshlands. Light blue arrows = direct water inputs stations, green arrows = water outlets stations, red crosses $=$ seasonal inputs and outlets stations that depends on the water level between main river and the marsh, white circles = sampling stations in the re-flooded marshes. 
major salt ions in 28 re-flooded marshes (13 in the Central, 5 in Al-Hawizeh, and 10 in the Al-Hammar marshlands) during the period from January 2006 to December 2006.

\section{Results and Discussion}

\subsection{Water Shortage}

The annual water discharge of the Tigris and the Euphrates Rivers has been significantly reduced for the last 50 years. Figure 2 shows the annual water discharge of the Two Rivers into the Mesopotamian marshlands from 1940 to 2007. The regression line shows the graduate reduction of the Two Rivers' water discharge during the recorded period. Generally, the figure indicates two periods of water discharge reduction. The first period was during the 1970's, in which many dams were constructed at the Tow Rivers' upstream in Turkey [5]. The second period was late 1990's, when the Iraqi government started drains the marshlands. During the pre-dam, the annual water discharge of the Two Rivers into the Mesopotamian marshlands from 1940 to 1970 was about $84.6 \times 10^{9} \mathrm{~m}^{3}$. After this period until 1990 's, the Mesopotamian marshlands lost more than $30 \%$ of their annual water discharge. The situation of water shortage become more complicated overtimes, unfortunately, the current annual water discharges of the two Rivers are still decreasing, and its average value from early inundation in 2003 to 2007 was about $13.8 \times 10^{9} \mathrm{~m}^{3}$. This indicate that the Mesopotamian marshland have lost more than $80 \%$ from their historical water input. This situation is dramatically affecting the current hydrological conditions of the re-flooded marshes. This also indicates that the existing quantity of water in the Two Rivers is not enough to re-cover the historical Mesopotamian's size. On the other hand, Figure 3 shows the monthly fluctuation of the recent water discharge of Tigris and Euphrates River compared to the historical monthly average fluctuation of the Euphrates River during the pre-dams construction taking from [5]. Obviously, the monthly water discharge fluctuations of the Two Rivers since the post-dams' construction period had dramatic change comparing to the historical water discharge fluctuation up to the 1970's. The impact has significantly eliminated the high fresh spring pulse and maintains constant water fluctuation until now. The loss of the huge spring pules had two main effects on the ecological and biological function of the marshlands by reducing the huge fresh water discharge and alter the vegetation and production cycle of the aquatic biota $[12,18]$. Along with the reduction in water discharge, the salinity concentrations among the direct water inputs of the Mesopotamian marshlands were significantly increased as it shown in the regression correlation between the current salinity concentration from May 2006 to February 2007 and the average historical salinity concentrations of the Tigris and Euphrates Rivers during 1958 (Figure 4). The increase of the average salinity level in the Two Rivers came along with the reduction in their water discharge and losing the fresh spring pulses late 1970's.

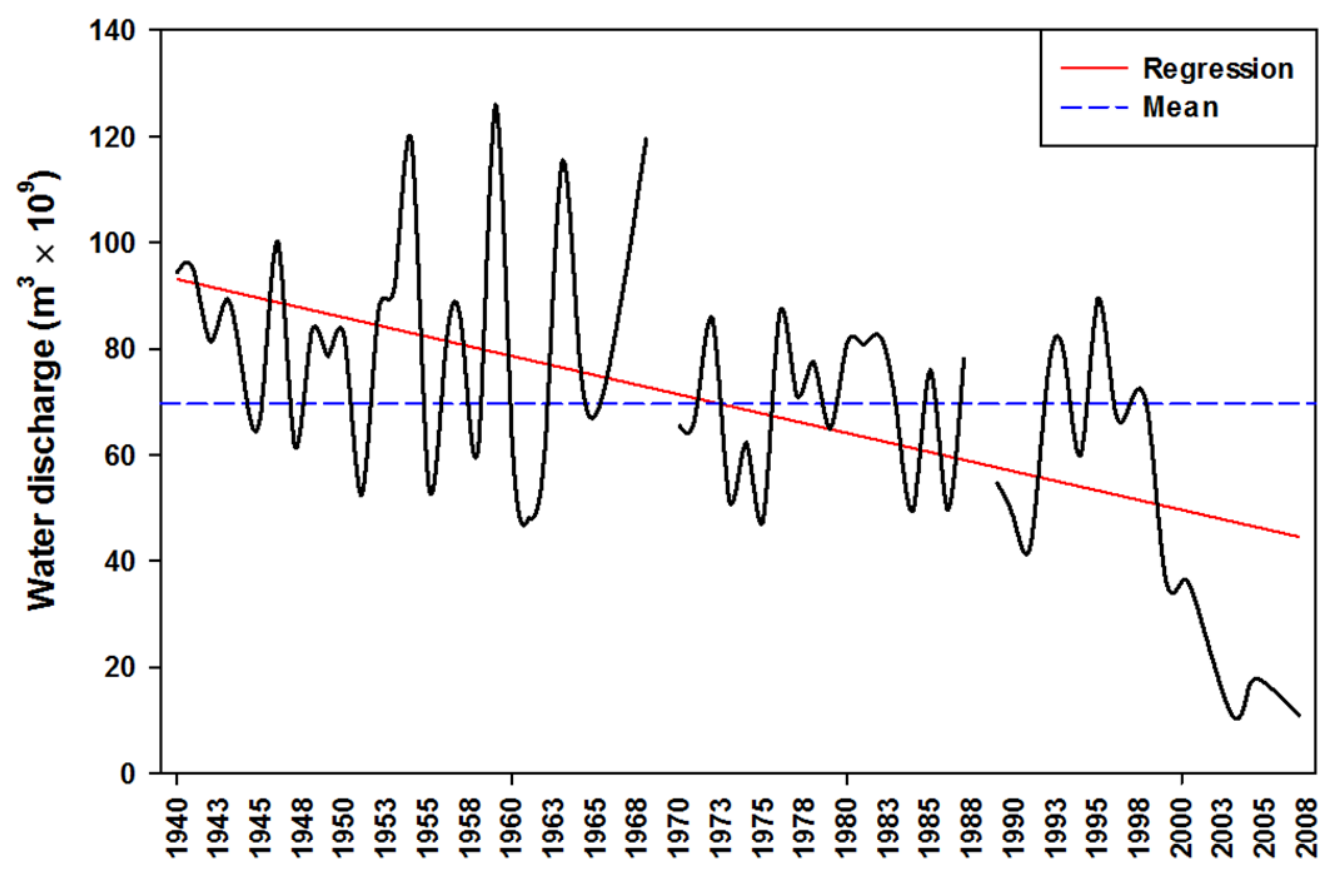

Figure 2. Annual water discharge of the Tigris and the Euphrates Rivers. Water discharges from 1940 to 2002 were measured at the closest input into the Mesopotamian marshlands. This period exclude the flood years (1969 and 1988). Water discharges from 2003 to 2007 were measured at the direct water inputs of the Mesopotamian marshlands. 


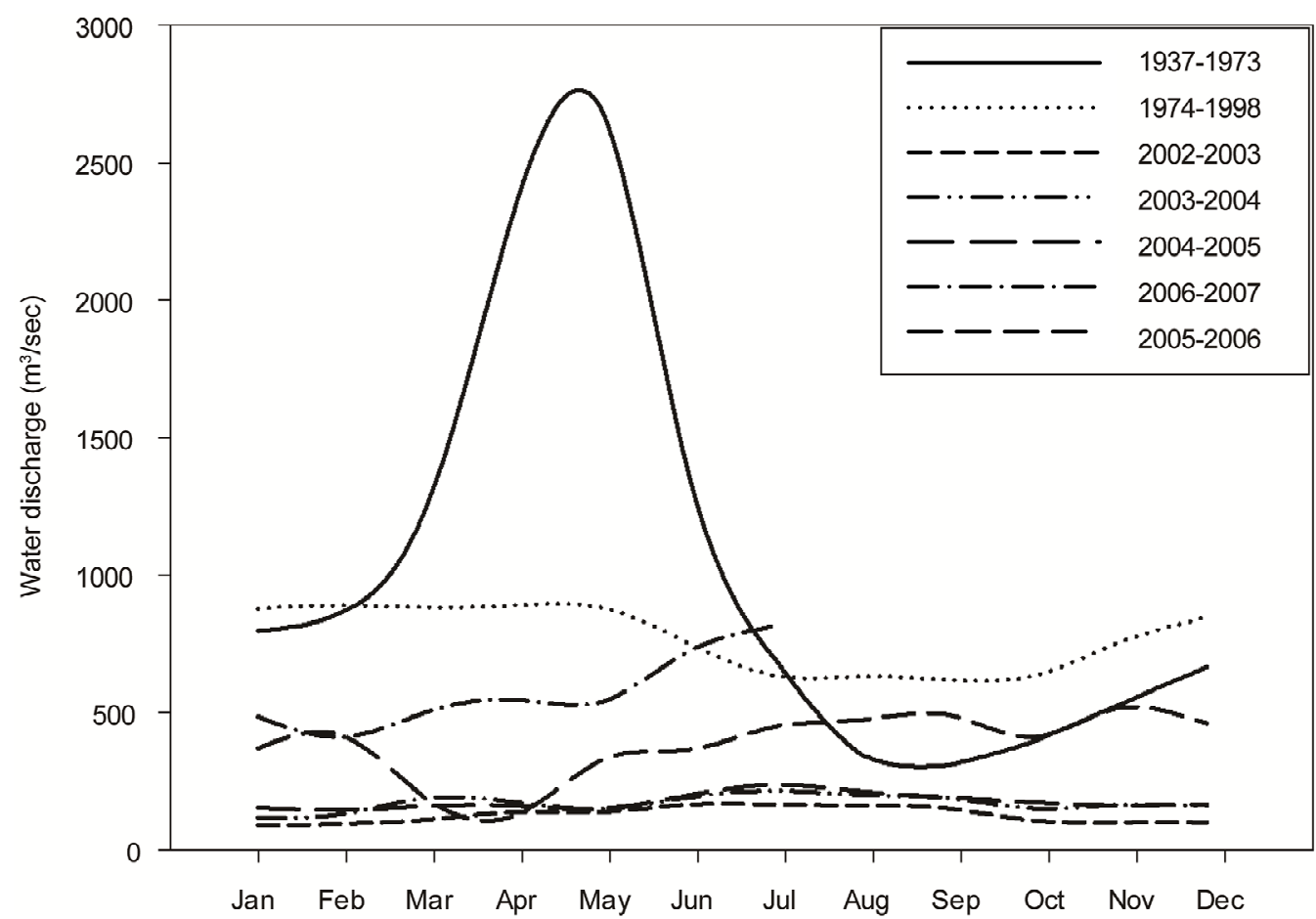

Figure 2. The monthly water discharge fluctuation of the Tigris and Euphrates River from 2002-2003 to 2006-2007 compared to the monthly average water discharge fluctuation of the Euphrates River pre-dams' construction (1937-1973) and the post-dams' constructions (1974-1998) taken from [5].

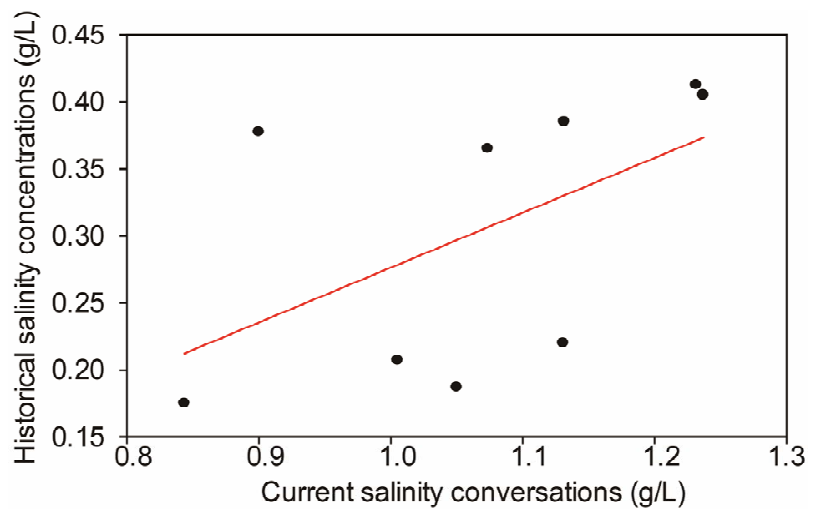

Figure 3. Regression correlation $\left(R^{2}=0.3\right)$ between the current average salinity concentration in direct water inputs of the Mesopotamian marshlands from May 2006 to February 2007 and the historical average salinity concentrations of the Tigris and the Euphrates Rivers from January to December 1958 taken from [2].

\subsection{Desiccation}

Salinity level in the Mesopotamian marshlands has been significantly increased over the past 40 years as it shown in Figure 5. This was clearly noticeable during the period of desiccation (1985-1991) to the first year of inundation (2004). From March 2005 to August 2008, the seasonal variation of the average salinity and major ions concentration were increased, especially in the Central and Al-Hammar marshlands. The results show that the

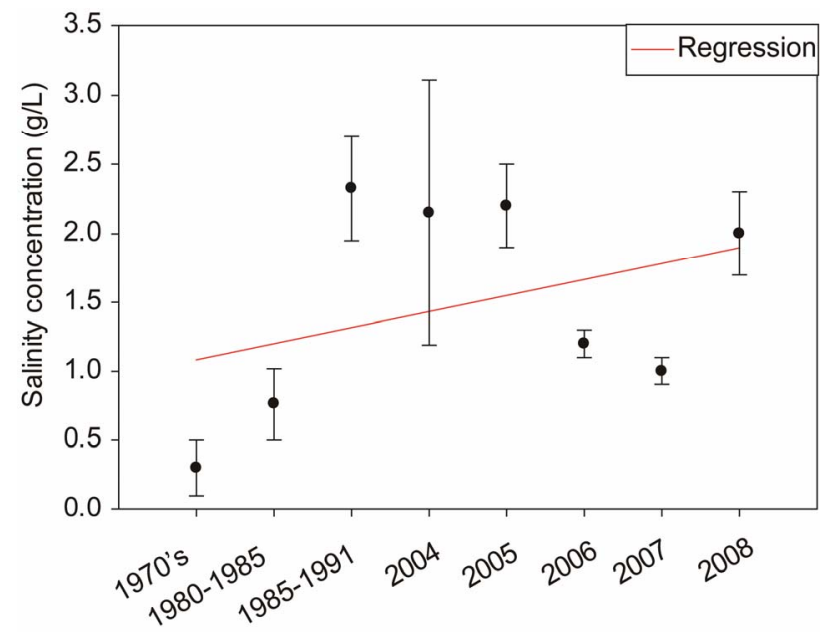

Figure 4. Overtime fluctuation of the average salinity concentrations (+SE) of the Mesopotamian marshlands.

chloride and sulfate ions concentrations were higher and more fluctuated than the calcium and magnesium ions within the samples stations (Figure 6). This increase in the average salinity level in the re-flooded marshes indicates is corresponded to the increase in the salinity level of the water inputs as well as the re-dissolve of the accumulated salts on the surface sediment in to the system. However, the fluctuation of the chloride and sulfate ions concentrations indicates the different resources of the salts within the water. Pearson correlation coefficient 

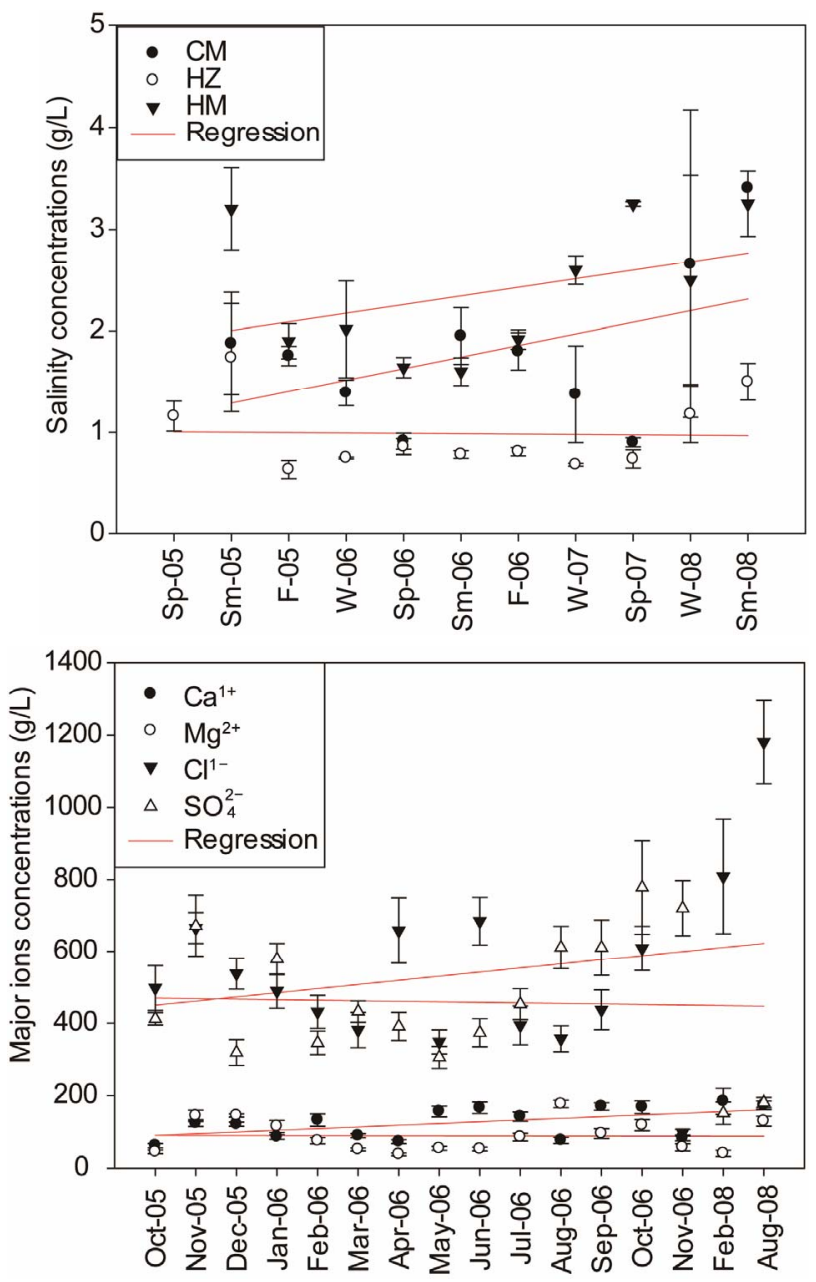

Figure 6. Seasonal average variation of the salinity and major ion concentrations (+SE) in the Central (CM), AlHawizeh (HZ), and Al-Hammar (HM) marshlands. Sp = spring, $\mathrm{Sm}=$ summer, $\mathrm{F}=$ fall, and $\mathrm{W}=$ winter.

shows a positive relationship between the average salinity and chloride ion in the Al-Hammar marshland water, while the salinity concentrations of the Central and AlHawizeh marshlands were slightly related to the increase in sulfate ion (Table 1). Since chloride is the dominant ion in Al-Hammar marshland, this indicates that this marsh has influenced by marine water via the tidal current of the Shatt Al-Arab River.

The PCA of the major ions' monthly variation in 28 re-flooded marshes shows significant differences in the salinity sources between the re-flooded marshes in the Al-Hawizeh and the re-flooded marshes in the Central and Al-Hammar. The graph also shows seasonal exchange in the dominant periods between the sulfate and chloride ions in the re-flooded marshes of the Central and Al-Hammar. Generally, the chloride ion is more dominant in the Central and Al-Hammar waters during the summer, when the sulfate becomes dominant during fall (Figure 7). On the other hand, the regression coefficient
Table 1. Matrix of Pearson correlation coefficient for salinity and major ions concentrations for the selected re-flooded marshes in the Mesopotamia.

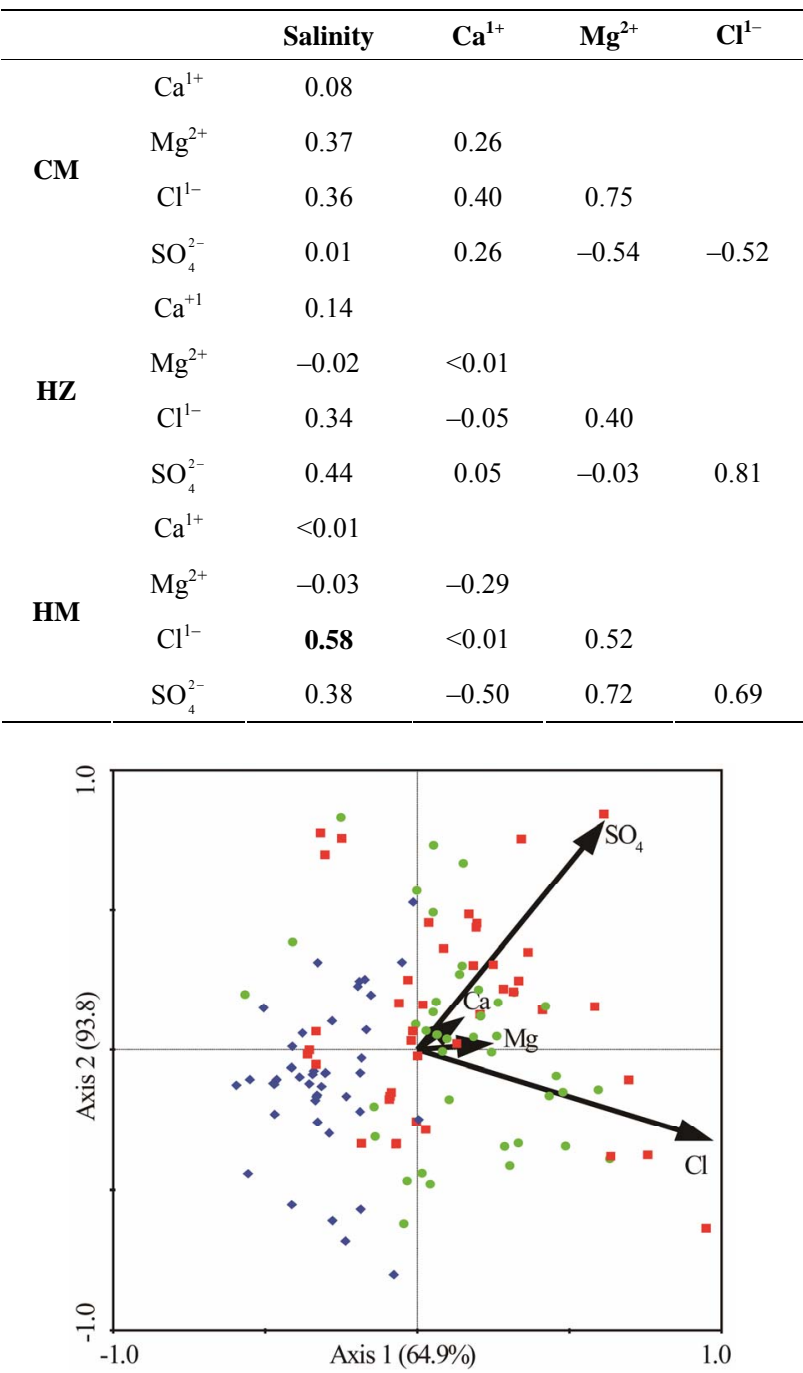

Figure 5. PCA of the major ions in the water of 28 re-flooded marshes in the Central (red squares), Al-Hawizeh (blue diamonds), and Al-Hammar marshlands (green circles. Axis 1 accounted for $64.0 \%$, Axis 2 accounted for $93.8 \%$, and axis 3 accounted for $\mathbf{9 8 . 7 \%}$ of the total variance. Chloride $\left(\mathrm{Cl}^{1-}\right)$ had strong positive loadings on Axis 1, while sulfate $\left(\mathrm{SO}_{4}^{2-}\right.$ ) had negative loading on Axis 2.

between the diurnal salinity concentrations and both chloride and sulfate ions in Al-Hammar (Al-Mashab station) and Al-Hawizeh (Um Al-Niaaj station) indicate no significant changes between the salinity versus sulfate ion or chloride ion concentration, while in Al-Hammar the both salinity and chloride values were increased and coincided with the tidal currents (Figure 8).

\section{Conclusion}

The overtime increase in the average salinity concentra- 


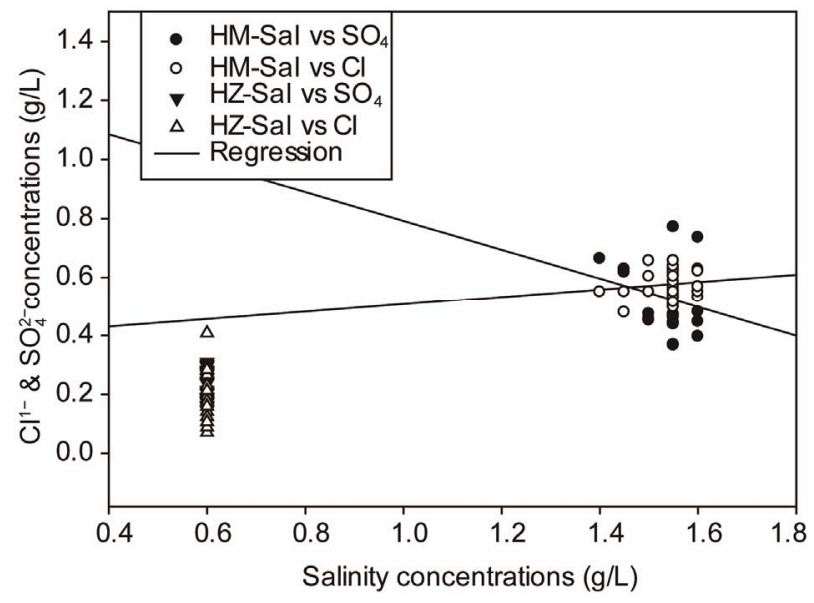

Figure 6. The regression coefficient between the diurnal salinity concentrations and both chloride ion $\left(R^{2}=0.13\right)$ and sulfate ions $\left(R^{2}=0.04\right)$ in Al-Hammar (Al-Mashab station) and Al-Hawizeh (Um Al-Niaaj station) recorded in December 2006.

tion in the Mesopotamian marshlands will have a huge negative impact on their ecological function and their biological structure. This risk can be extended to affect the aquatic biodiversity of the newly flooded marshes and change their assemblages. Since the historical Mesopotamian marshlands used to be fresh water body, the new hydrological conditions have indicated that both water shortage and desiccation processes will lead convert what left of marshes into brackish or even saline systems. The consequences of these changes can result in losing the historical uniqueness of the Mesopotamian marshlands and thus the development of completely new ecosystem. Obviously, there are huge amounts of water in the Tigris and Euphrates Rivers that are used either for irrigation or storage in the reservoirs to prevent the rivers from flushing all the accumulated salts components that accumulated on the surface sediment as a result of desiccation. On top of that these rivers are also have been loaded with high amount of salts due to the loose of the fresh spring pulses and the decrease of the water discharge. After almost nine years of re-flooding the Mesopotamian marshlands, the IMWR reported that only $40 \%$ of the actual size of the Mesopotamian marshlands is accomplished. This indicates that the Iraqi government is not able to manage the re-flooding processes which require sufficient amounts of fresh water to inundate the completely dried areas. The cold war of water share between Iraq and his neighbours become the main factor in the existence of the Iraqi marshlands. The significant differences between the major ions concentrations among the three marshlands indicate the differences in the water sources for each marsh. Generally, the high chloride ion concentrations in the Al-Hammar marshland as oppose to the sulfate ion concentrations are indicative of marine water influence, which mainly attributed to the tidal ef fect of Shatt Al-Arab River; while sulfate ion concentrations were higher than chloride ion in the Al-Hawizeh marsh is an indicator for fresh water sources. The impact of draining the Mesopotamian marshlands was correspond to the huge accumulation of salts that concentrated and compacted overtime on top of the sediments because of the graduate water evaporation; however, after reflooding, the high salinity concentrations were many attributed to the dissolution of deposited salts, pollution and evaporation.

\section{Acknowledgements}

This work is a contribution from the Canada-Iraq Marshlands Initiative (CIMI). We gratefully acknowledge financial support from the Iraqi Ministry of Higher Education and Research and the Canadian International Development Agency.

\section{REFERENCES}

[1] D. A. Scott, "A Directory of Wetlands in the Middle East," IUCN, UK, 1995, p. 560.

[2] J. Rzoska, "Euphrates and Tigris, the Mesopotamian Ecology and Destiny," W. Junk, The Hague, Boston, Hingham, 1980.

[3] J. F. Talling and I. B. Talling, "The Chemical Composition of African Lake Waters," Internationale Revue der gesamten Hydrobiologie und Hydrographie, Vol. 50, No. 3, 1965, pp. 421-463. doi:10.1002/iroh.19650500307

[4] M. I. Al-Hamed, "Limnological Study on the Inland Waters of Iraq," Bulletin of the Iraq Natural History Museum, Vol. 3, No. 5, 1966, pp. 1-22.

[5] H. Partow, "The Mesopotamian Marshlands: Demise of an Ecosystem-Division of Early Warning and Assessment," United Nations Environment Programme, Nairobi, 2001, p. 46.

[6] Iraqi Ministry of Water Resources (IMWR), "Studying the Rehabilitation of Al-Hawizeh Marsh Ecological System," Centre for the Restoration of Marshes, Iraq, 2006, p. 79.

[7] F. Al-Manssori, "Future Assessment of Southern Iraqi Marshes," Ph.D. Thesis, University of Basra, Basra, 2008, p. 164.

[8] Iraq Foundation (IF), "Draft Report Physical Characteristics of Mesopotamian Marshlands of Southern Iraq," Background Material Prepared for the Technical Advisory Panel Eden Again Project, 2003, p. 45.

[9] Florida Department of Environmental Protection (FDEP), "Restoration Procedures Manual for Public Lands in Florida," The Nature Conservancy, 1998, p. 124.

[10] D. W. Blinn, "Diatom Community Structure Change the Physiochemical Gradients in Saline Lakes," Ecology, Vol. 74, No. 4, 1993, pp. 1246-1263. doi:10.2307/1940494

[11] B. C. Chessman and W. D. Williams, "Distribution of Fish in Inland Saline Waters in Victoria, Australia," Australian Journal of Marine and Freshwater Research, Vol. 
25, No. 1, 1974, pp. 167-172. doi:10.1071/MF9740167

[12] R. H. Froend, E. M. Heddle, D. H. Bell and A. J. McConb, "Effect of Salinity and Waterlogging on the Vegetation of Lake Toolibin, Western Australia," Australian Journal of Ecology, Vol. 12, No. 3, 1987, pp. 281-298. doi:10.1111/j.1442-9993.1987.tb00949.x

[13] D. L. Nielsen, M. A. Brock, G. N. Rees and D. S. Baldwin, "Effect of Increasing Salinity on Fresh Ecosystems in Australia," Australian Journal of Botany, Vol. 51, No. 6, 2003, pp. 655-665. doi:10.1071/BT02115

[14] S. S. Mahamed, "Phosphorus and Nitrogen in Al-Hawizeh Marshes, Southern Iraq," M.Sc. Thesis, University of Waterloo, Ontario, 2008.
[15] C. J. Richardson and N. A. Hussain, "Restoration the Garden of Eden: An Ecological Assessment of the Marshes of Iraq," BioScience, Vol. 56, No. 6, 2006, pp. 477-489. doi:10.1641/0006-3568(2006)56[477:RTGOEA]2.0.CO;2

[16] Americana Public Health Association (APHA), "Standard Methods for Examination of Water and Waste Water," 20th Edition, Washington DC, 1979.

[17] N. A. Husain, "Ahwar of Iraq: Environmental Approach," University of Bassra, Iraq, 1994, p. 290.

[18] W. Stumm and J. Morgan, “Aquatic Chemistry: Chemical Equilibrium and Rates in Natural Waters," 3rd Edition, John Wiley and Sons, New York, 1995. 